УДК 656.224:330.13

\title{
МЕТОДИЧНИЙ ПІДХІД ЩОДО ВИЗНАЧЕННЯ ОПТИМАЛЬНИХ ЗОН КУРСУВАННЯ РІЗНИХ ВИДІВ ПАСАЖИРСЬКИХ ПОЇЗДІВ
}

\author{
Бараш Ю. С., д.е.н., професор, \\ Матусевич О.О., ст. викладач (ДНУЗТ)
}

\begin{abstract}
Розроблено методичний підхід щзодо визначення оптимальних зон курсування пасажсирських поїздів різних видів, який базується на зниженні їх експлуатаційних витрат та підвищенні швидкості руху при зміні організації руху за новою класифікацією поӥздів, щчо дозволить підняти економічну ефективність або знизити збитковість пасажсирських перевезень та підвищити їх конкурентоспроможність на ринку пасажсирських транспортних послуг.
\end{abstract}

Ключові слова: пасажирський рух, пасажирські поӥзди, доходи від перевезень, витрати від перевезень, ефективність перевезень, збитковість перевезень.

\section{МЕТОДИЧЕСКИЙ ПОДХОД К ОПРЕДЕЛЕНИЮ ОПТИМАЛЬНЫХ ЗОН КУРСИРОВАНИЯ РАЗНЫХ ВИДОВ ПАССАЖИРСКИХ ПОЕЗДОВ}

Бараш Ю. С., о.э.н., профессор, Матусевич А. А., ст. преподаватель, (ДНУЗТ)

Разработано методический подход по определению оптимальных зон курсирования пассажирских поездов разных видов, который основывается на снижении их эксплуатационных расходов и повышении скорости движения при изменении организации движения по новой классификации поездов, что позволит поднять экономическую эффективность или снизить убыточность пассажирских перевозок и повысить их конкурентоспособность на рынке пассажирских транспортных услуг.

Ключевые слова: пассажирское движение, пассажирские поезда, доходы от перевозок, расходы от перевозок, эффективность перевозок, убыточность перевозок.

\section{METHODOLOGICAL APPROACHES TO THE DETERMINATION OF THE OPTIMAL AREAS PLYING DIFFERENT TYPES OF PASSENGER TRAINS}

\author{
Barash Y. S., Doctor of Economics, professor, \\ Matusevich A. A., senior lecturer( Dnepropetrovsk National University of Railway Transport \\ named after Academician V. Lazaryan)
}

A methodical approach to determine the optimal cruising zones of all types passenger trains was developed. This approach is based on reducing operating costs and increasing the speed when changing organization of trains movement according with new trains classification. This will raise economic efficiency or reduce losses of passenger transportations.

Keywords: passenger traffic, passenger trains, revenues of transportations, costs of transportations, efficiency of transportation, unprofitability of transportations.

Вступ. Зараз пасажирське господарство займається основною діяльністю (пасажирські перевезення зі швидкістю до 160 км / год) і підсобно-допоміжною діяльністю для додаткового завантаження основних фондів структурних підрозділів залізниць. Для повернення втраченої частки пасажирських перевезень та захоплення суміжних секторів транспортного ринку залізничний транспорт мусить суттєво підвищити ефективність пасажирських перевезень, впровадити нові швидкісні комфортні перевезення та вдосконалити сучасні види транспортних послуг.

Якщо раніше транспортні послуги були зорієнтовані на пасажира без значних вимог до ціни, швидкості та комфорту, то останнім часом залізничний транспорт враховує потреби різних категорій споживачів транспортних послуг. На залізниці почали надходити вагони нового покоління, які побудовані 3 урахуванням європейських стандартів якості. Відбудовано вокзали, організовано рух швидкісних поїздів 3
(C) Бараш Ю.С.,

Матусевич O.O.
Вісник економіки транспорту і промисловості № 50, 2015 
вагонами для комфортної поїздки інвалідів, підвищена швидкість руху окремих поїздів.

Подальші шляхи підвищення ефективності пасажирських перевезень в Україні слід виконувати за таким планом:

- створення інвестиційно-інноваційної моделі розвитку пасажирського господарства 3 впровадженням прогресивних технологій у транспортний процес;

- реформування системи управління пасажирськими перевезеннями шляхом побудови вертикально-інтегрованої (функціональної) структури;

- технічне переоснащення виробничої бази пасажирського господарства за умови впровадження процесів простого та розширеного відтворення основних фондів;

- модернізація рухомого складу, його переоснащення на основі високої економічної ефективності виробництва;

- впровадження

прогресивних

економічних технологій та організаційних заходів у процес пасажирських перевезень.

Але в умовах відсутності інвестицій та власних коштів, суттєвого скорочення обсягів пасажирських перевезень на перший план постає проблема підвищення ефективності пасажирських перевезень без значних капітальних вкладень. Цю задачу частково можна вирішити якщо поставити за мету мінімізувати витрати на курсування різних видів поїздів за умови гнучкого регулювання структури поїзду, раціональної тарифної політики, визначення оптимальних зон обертання приміських, регіональних, міжрегіональних, швидкісних поїздів та поїздів дальнього прямування. Саме вирішенню останньої задачі присвяченні дослідження, що наведені нижче.

Аналіз останніх досліджень і публікацій. Проблему підвищення ефективності пасажирських перевезень за різними напрямками досліджували радянські та українські вчені А. П. Абрамов, I. В. Бєлов, В. Г. Галабурда, В. М. Гурнак, М. Н. Біленький, О. В. Дмитренко, М. У. Дмитрієв, Ф. П. Кочнєв, М. В. Правдін, Н. Г. Сміхова, В. Л. Дикань, Ю. Ф. Кулаєв, М. В. Макаренко, Є. М. Сич, Ю М. Цвєтов, А. М. Новикова, О. Г. Дейнека, Ю. С. Бараш, Н. М. Колесникова, I. М. Аксьонов, Ю. Є. Пащенко, В. В. Скалозуб, В. М. Самсонкін, О. М. Гненний, М. Б. Курган, I. П. Корженевич, Т. С. Мельник, М. В. Гненний, В. П. Гудкова, О. М. Гудков, С. І. Балака, О. М. Кривопішин, Л. М. Лобойко, В. І. Сіраков, О. В. Семенцова, К. В. Шерепа, В. О. Задоя, О. П. Пінчук, Г. С. П’ятигорець, Т. Ю. Чаркіна, Н. О. Божок та ін. Однак задача підвищення ефективності пасажирських перевезень за рахунок оптимізації зон курсування пасажирських поїздів досліджувалася лише науковцями Дніпропетровського національного університету залізничного транспорту імені академіка В. Лазаряна (ДНУЗТ) в наукових працях $[4,15,16]$. Ця комплексна задача вирішувалася одночасно за такими напрямками:

- удосконалення

класифікації пасажирських поїздів в Україні з урахуванням отримання фінансової самостійності великими містами та областями [14 ];

- визначення фактичної рентабельності окремого пасажирського поїзду на конкретних напрямках руху [17];

- побудова нових тарифів на перевезення пасажирів за методикою Дніпропетровського національного університету залізничного транспорту імені академіка В. Лазаряна [18];

- $\quad$ розробка методичного підходу стосовно підвищення ефективності використання усіх видів пасажирських поїздів за рахунок оптимізації зон їх курсування залежно від фактичної збитковості або малої рентабельності цих перевезень;

- визначення оптимальних зон курсування приміських, регіональних та міжрегіональних поїздів [19];

- визначення оптимальних зон курсування швидкісних поїздів [20].

Виділення невирішених частин загальної проблеми. Майже усі вказані вище питання вже вирішенні в Галузевій науково-дослідній лабораторії «Економіка та управління залізничним транспортом» ДНУЗТ. Нижче вперше наведений методичний підхід щодо підвищення ефективності використання усіх видів пасажирських поїздів за рахунок оптимізації зон їх курсування залежно від фактичної збитковості або малої рентабельності цих перевезень.

Мета. Розробити методичний підхід щодо підвищення ефективності використання усіх видів пасажирських поїздів за рахунок оптимізації зон їх курсування залежно від фактичної збитковості або малої рентабельності цих перевезень.

Для вирішення задач такого класу в роботі запропоновано удосконалену методику визначення оптимальних зон курсування різних видів пасажирських поїздів, яка побудована на основі концепції маржинального доходу з використанням графічного методу. Ця методика дозволить визначити раціональні зони курсування усіх видів пасажирських поїздів для суттєвого зменшення їх збитковості.

Виклад основного матеріалу

дослідження. Подальші дослідження даної проблеми виконувалися на основі аналізу існуючої калькуляції собівартості пасажирських перевезень за видами сполучень за попередні роки $[5,21]$ та наукової праці [17]. На конкретному прикладі для поїздів дальнього сполучення розглянемо принцип визначення беззбиткових пасажирських перевезень. Кожна зі статей витрат була віднесена 
до умовно-змінних (рис. 1) або умовно-постійних витрат (рис. 2).

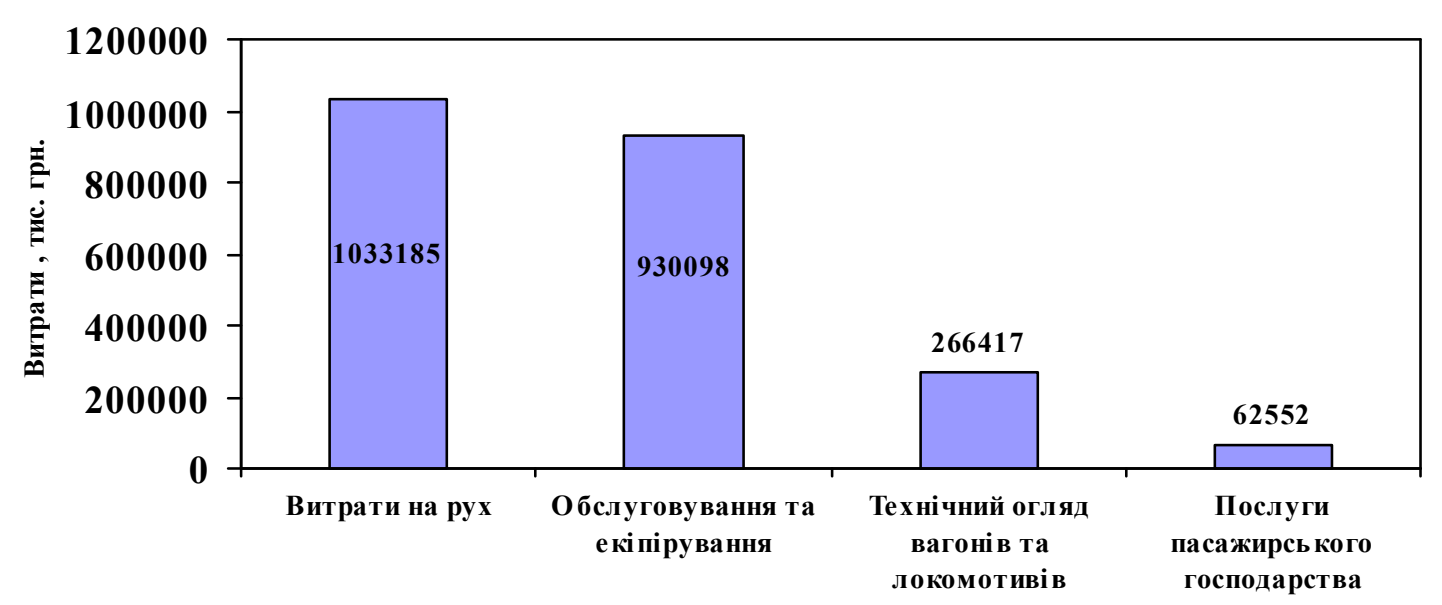

Рис. 1. Умовно-змінні витрати на перевезення пасажирів y дальньому сполученні (джерело [22] з доробкою авторів)

До умовно-змінних витрат віднесені витрати, що пов’язані:

- $з$ рухом пасажирських поїздів;

- обслуговуванням поїздів під час руху та на станціях;
- екіпіруванням пасажирських вагонів на технічній станції;

- екіпіруванням пасажирських локомотивів;

- технічним оглядом вагонів та локомотивів;

- послугою з продажу квитків;

- послугою з прийому та видачі багажу.

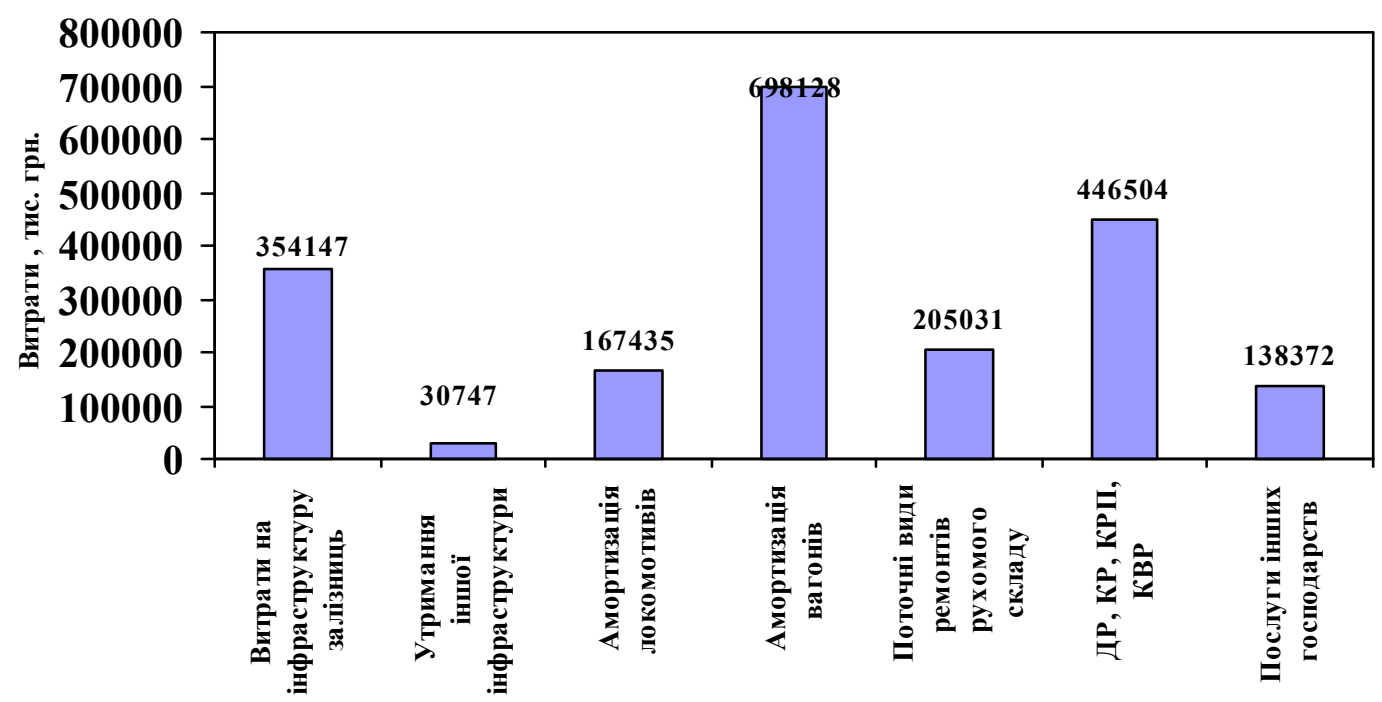

Рис. 2. Умовно-постійні витрати на перевезення пасажирів у дальньому сполученні (джерело [22] з доробкою авторів)

До умовно-постійних витрат (рис. 2) віднесені витрати, що пов'язані:

- 3 утриманням та обслуговуванням інфраструктури залізниць усіма господарствами;

- 3 утриманням та обслуговуванням іншої інфраструктури (будівель та споруд, які не пов'язані 3 колією, штучними спорудами, контактною мережею, повздовжніми ЛЕП, кабельними лініями);

- $з$ амортизацією рухомого складу;
- 3 поточними видами ремонту локомотивів;

- 3 деповськими ремонтами вагонів та капітальними видами ремонту рухомого складу;

- 3 послугами інших господарств.

Для подальших досліджень необхідно провести аналіз «витрати - обсяг діяльності прибуток», для чого використаємо графік беззбитковості пасажирських перевезень у дальньому сполученні за правилами графічного 
визначення маржинального доходу (рис.3), запропонований у роботі [6].

Передбачається, що аналіз здійснюється в межах релевантного діапазону, в якому загальна сума умовно-постійних витрат залишається незмінною, а функції умовно-змінних витрат, реального доходу та маржинального доходу $є$ лінійними залежно від обсягу перевезень. При суттєвому збільшенні кількості рухомого складу для перевезення пасажирів треба виконувати аналіз витрат у новому релевантному діапазоні 3 іншими показниками змінних та постійних витрат.

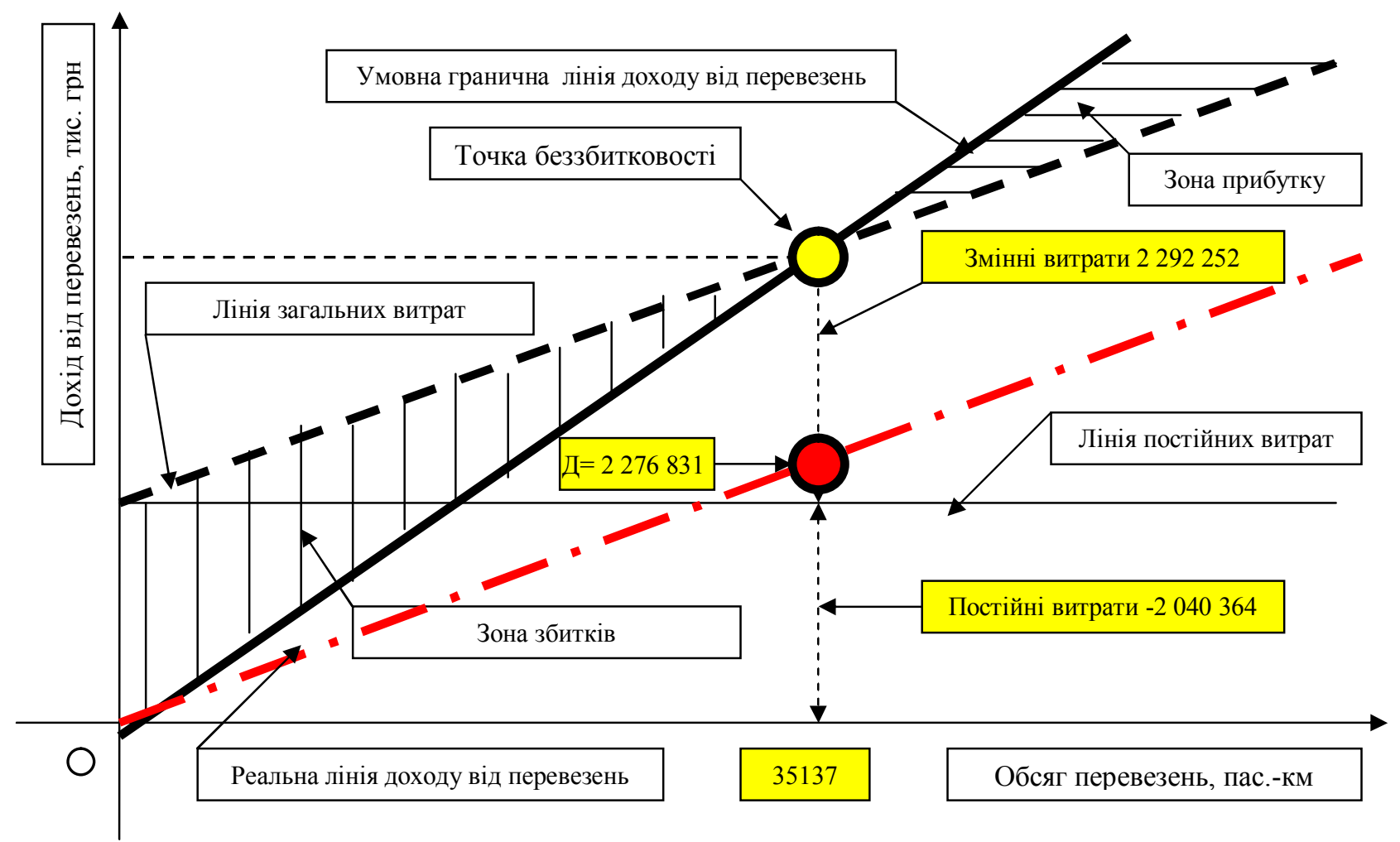

Рис. 3. Графік беззбитковості пасажирських перевезень [2]

На горизонтальну вісь наносимо значення пасажирських перевезень у пас.-км для певного розрахункового року. 3 даної точки будуємо вгору відрізок паралельно вертикальної осі, значення якого дорівнює постійним витратам - 2040364 тис. грн. Потім угору додаємо відрізок, значення якого дорівнює змінним витратам - 2292252 тис. грн. Побудований таким чином загальний відрізок дорівнює витратам від перевезення пасажирів у розрахунковому році - 4332616 тис. грн. Через дану точку та точку перетину лінії постійних витрат 3 вертикальною віссю проводимо лінію загальних витрат (жирний пунктир). Якщо провести 3 точки нуль на початку координат пряму до точки, що дорівнює значенню витрат на перевезення пасажирів у розрахунковому році, то отримаємо лінію умовних доходів від перевезень (показано жирним). Точка перетину даної лінії 3 лінією загальних витрат на перевезення $\epsilon$ точка беззбитковості, тобто точка, в якій величина доходів від перевезень дорівнює значенню величіні загальних витрат (позначена кільцем).

На рис. 3 жирним показана умовна лінія доходу від перевезень, яка не $є$ реальною, а лише ілюструє знаходження точки беззбитковості. Таку точку знайти на графіку, за умови нанесення на нього реального доходу від пасажирських перевезень в дальньому сполученні, не вдається, оскільки реальна лінія доходу (показана штрихпунктиром) не перетинається 3 лінією витрат у межах рисунка.

На рис. 4 зроблені інші побудови лінії загальних витрат. Спочатку 3 точки нуль нарисована лінія змінних витрат, а потім зверху до неї на дистанції 2040364 тис. грн нарисована паралельно лінія загальних витрат. При такій побудові лінії загальних витрат на перевезення пасажирів нічого не змінилося. Також, як і на графіку (рис. 3) проведено через точку беззбитковості лінію умовного та нижче лінію реального доходу від перевезень. Додатково 
показані кути між горизонтальною віссю та лініями реального доходу, умовного доходу та витрат відповідно $\alpha_{1}, \alpha_{1}^{1}, \alpha_{2} .3$ рисунка випливає, що $\operatorname{tg} \alpha_{1}=\quad Д_{p} / n \kappa ; \quad \operatorname{tg} \alpha_{1}^{1}=Д_{y} / n \kappa ;$ $\operatorname{tg} \alpha_{2}=3 B / n \kappa$, звідси:

$$
\frac{Д_{y}}{\operatorname{tg} \alpha_{1}^{1}}=\frac{3 B+\Pi B}{\operatorname{tg} \alpha_{1}^{1}}=\frac{Д_{p}}{\operatorname{tg} \alpha_{1}}=\frac{3 B}{\operatorname{tg} \alpha_{2}},
$$

(1) де $Д_{y}-$ умовний дохід від перевезень пасажирів у дальньому сполученні, коли дохід дорівнює витратам;

$$
Д_{p}-\text { реальний дохід від перевезення }
$$

пасажирів у дальньому сполученні в розрахунковому році;

3B - змінні витрати від перевезення пасажирів у дальньому сполученні в розрахунковому році;

$\Pi B$ - постійні витрати від перевезення пасажирів у дальньому сполученні в розрахунковому році.

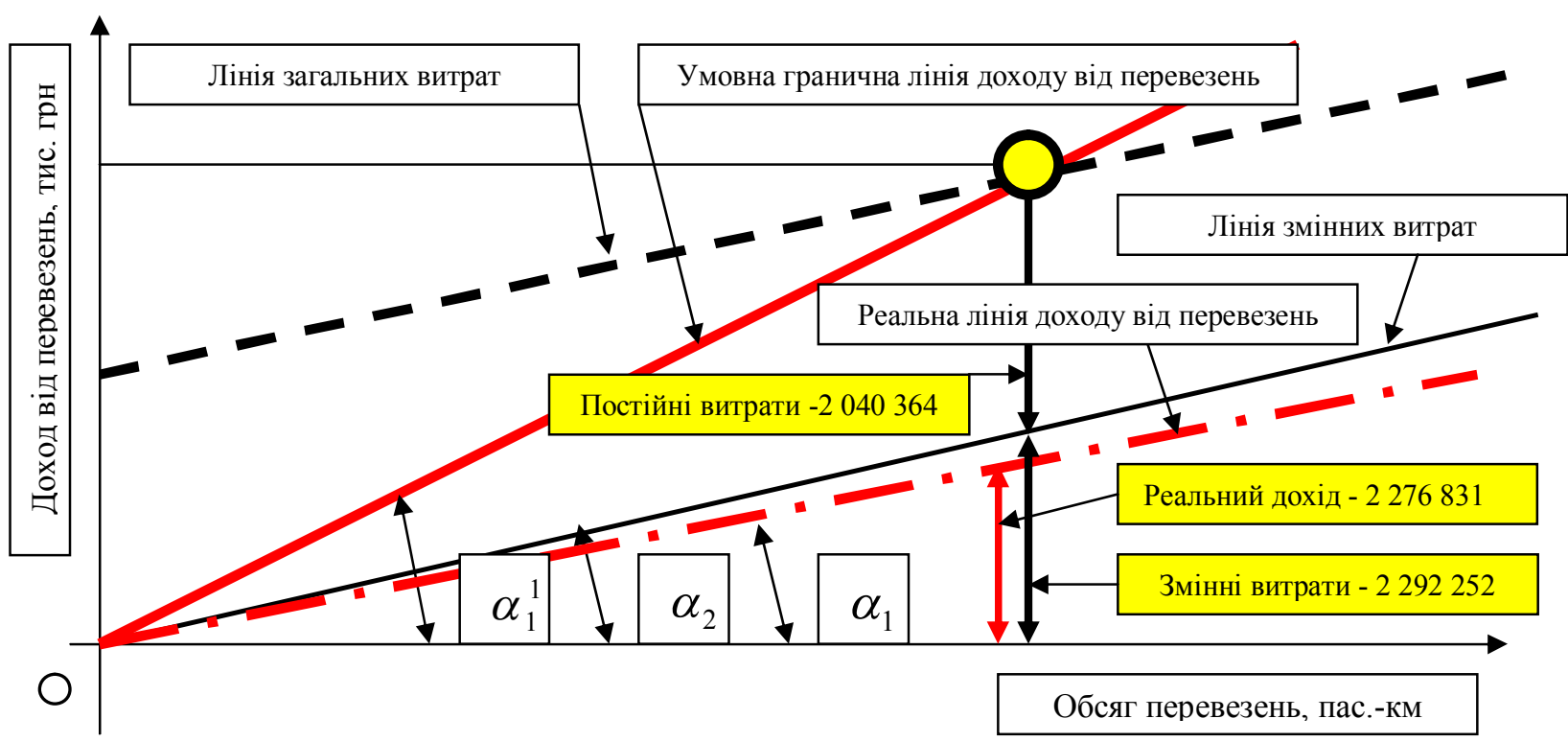

Рис. 4. Графік беззбитковості пасажирських перевезень з використанням маржинального доходу [2]

Подальший аналіз показує, для того щоб досягти точки беззбитковості при перевезенні пасажирів у дальньому сполученні, необхідно щоб кут $\alpha_{1}$ був завжди більший за $\alpha_{2}$ (дивись кут $\alpha_{1}^{1}$ ). Якщо навпаки кут $\alpha_{1}$ менший за $\alpha_{2}$, то перевезення пасажирів у дальньому сполученні завжди будуть збитковими, навіть тоді, коли постійні витрати будуть дорівнювати нулю. Це вказує на:

- необгрунтовану побудову тарифів;

- неоптимальну структуру поїзда;

- низьку швидкість руху при великій відстані курсування, яка не приваблює пасажирів;

- відсутність необхідного комфорту;

- довгий термін подорожі.

Всі ці фактори впливають на низький попит пасажирів, що існує на даному напрямку, оскільки доходи від перевезень пасажирів не покривають навіть змінні витрати.

Для підвищення ефективності курсування різних видів пасажирських поїздів існує два підходи:

1. Підвищення доходу від перевезення пасажирів даним поїздом на конкретному напрямку з урахуванням вищенаведених факторів.

2. Зниження експлуатаційних витрат на курсування даного поїзду на конкретному напрямку за рахунок:

- встановлення оптимальної композиції поїзда;

- скорочення деяких зупинок 3 малою кількістю пасажирів;

- оптимізації відстані курсування пасажирського поїзду, якщо його населеність суттєво спливає після певної зони;

- зміни графіку руху та періоду курсування поїздів на конкретному напрямку;

- зміни організації руху та кільцювання пасажирських поїздів на конкретному напрямку.

Майже усі вказані вище заходи вже досліджувалися різними науковцями, тому дана 
робота присвячена саме оптимізації відстані курсування будь-якого пасажирського поїзду.

Наприклад, у приміському сполученні багато поїздів курсують на відстань більш ніж 170200 км. При цьому поїзд робить велику кількість зупинок, швидкість руху низька, а основна маса пасажирів в Україні подорожує на відстань до 70 км. Далі потік пасажирів спливає, поїзд рухається з низькою населеністю. У цьому випадку слід знайти оптимальну відстань поїзда, при якій значна кількість пасажирів буде перевезена в даній зоні, витрати значно скорочуються, а точка беззбитковості буде знаходитися майже поряд із середньою відстанню перевезення пасажирів у приміському сполученні в Україні.

У науковій праці [19] було проведено аналіз за допомогою маржинального доходу, який показав, що на напрямку Дніпропетровськ П'ятихатки економічно доцільно виконувати курсування приміських пасажирських поїздів лише до станції Верхівцеве (рис. 5). При цьому збитки від перевезень пасажирів будуть становити 5 млн грн на рік або 2,4 \% проти тих, що існують - 55,5 млн грн., що дозволить отримати додатковий ефект - 50,5 млн грн.

У науковій праці [20] було проведено аналіз за допомогою маржинального доходу щодо визначення раціональних зон курсування швидкісних поїздів.

Дільницю Верхівцеве - П'ятихатки доцільно обслуговувати рейковим автобусом, який буде курсувати для перевезення робочої зміни працівників Придніпровської залізниці, оскільки інших пасажирів на цій дільниці дуже мало. Крім того, на даному напрямку курсує багато пасажирських поїздів, які зупиняються на станції П'ятихатки.

Аналогічні розрахунки слід виконати для визначення раціональної відстані курсування регіональних та міжрегіональних поїздів. В цьому випадку слід більше уваги приділяти не зниженню збитковості, а навпаки, необхідністю скорочення кількості зупинок поїзда та підвищення швидкості руху. Крім того, це дозволить підвищити доходи від перевезень за рахунок підвищення тарифів та залучення додаткових пасажирів 3 автобусних перевезень.

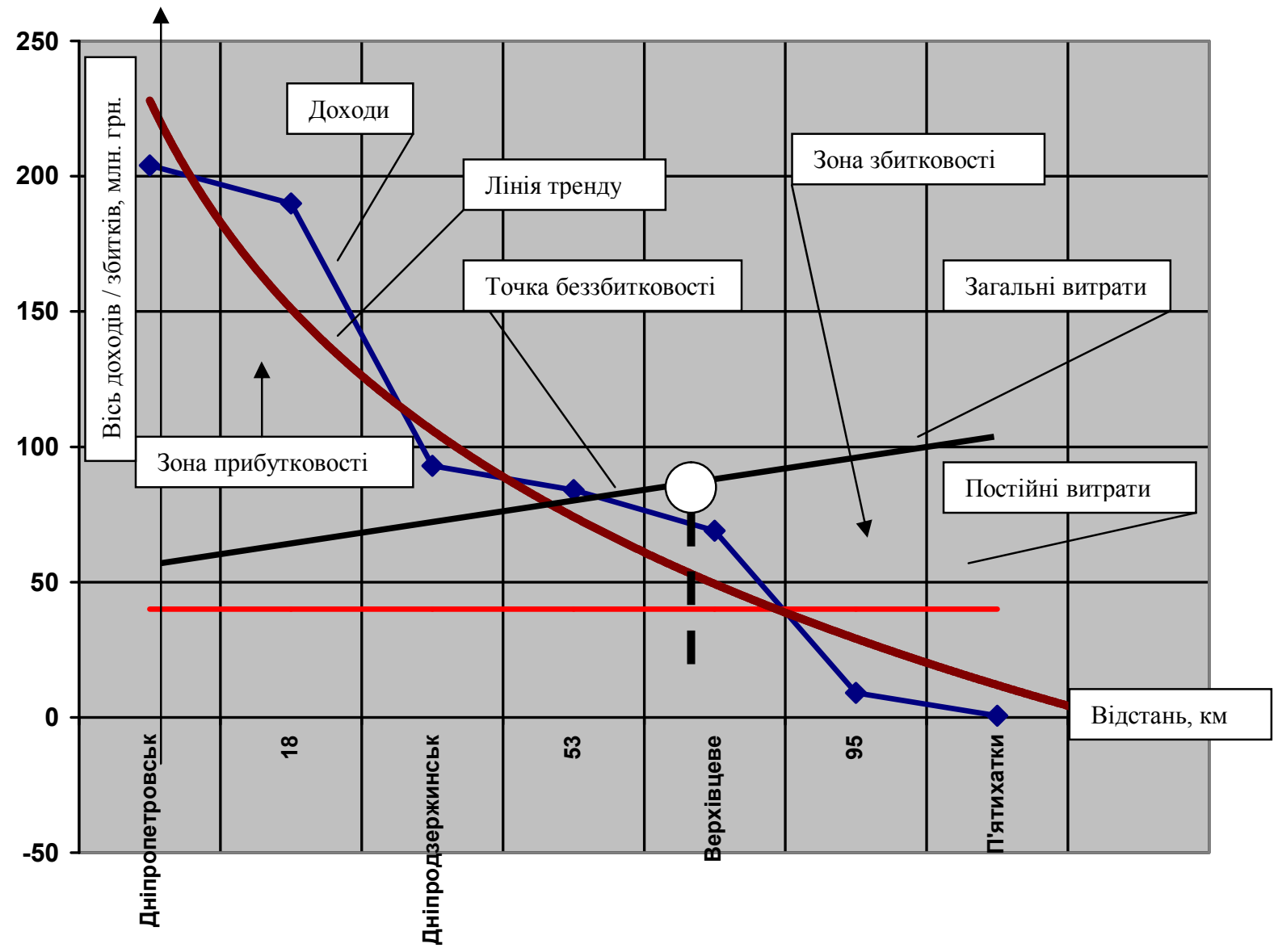

Рис. 5. Графік доходу від перевезення пасажирів на напрямку Дніпропетровськ - П'ятихатки (джерело [2] з доробкою авторів) 


\begin{abstract}
Висновки. На основі проведених досліджень було встановлено:

1. Принципи визначення експлуатаційних витрат на перевезення пасажирів окремим поїздом за допомогою калькуляції собівартості пасажирських перевезень за видами сполучень (статистична форма 10 зал) та розподіл їх на умовні-змінні та умовно-постійні.

2. Розроблено методичний підхід щодо визначення оптимальних зон курсування пасажирських поїздів різних видів, який базується на зниженні їх експлуатаційних витрат та збільшенні дохідності за рахунок врахування реальної кількості пасажирів на даному напрямку та дальності їх поїздки, підвищенні швидкості руху та зміни організації обігу за новою класифікацією поїздів, що дозволить підняти економічну ефективність або знизити збитковість пасажирських перевезень та підвищити їх конкурентоспроможність на ринку пасажирських транспортних послуг. Впровадження вказаної методики дозволить приватному акціонерному товариству «Українські залізниці» суттєво знизити збитковість пасажирських перевезень і поступово підвищити прибутковість своєї діяльності.
\end{abstract}

\section{СПИСОК ЛІТЕРАТУРИ}

1. Бараш Ю. С. Сравнение видов транспорта с учетом устойчивого развития общества / Ю. С. Бараш, И. П. Корженевич, П. А. Лихопек. ISSN 2309-82IX (Print), ISSN 2310-2438 (Online) Збірник наукових праць Дніпропетровського національного університету залізничного транспорту імені академіка В. Лазаряна «Проблеми економіки транспорту», 2013, вип. 6. // Вісн. Дніпропетр. нац. ун-ту залізн. трансп. ім. акад. В. Лазаряна. - Д. : Вид-во Дніпропетр. нац. ун-ту залізн. трансп. ім. акад. В. Лазаряна. - 2009. - Вип. 28. - С. 210-214.

2. Бараш Ю. С. Теоретико-методичний підхід до визначення конкурентоспроможності послуг, що надаються пасажирськими видами транспорту / Ю. С. Бараш А. А. Покотілов, Т. Ю. Чаркіна // Вісн. Дніпропетр. нац. ун-ту залізн. трансп. ім. акад. В. Лазаряна. - Д. : Вид-во Дніпропетр. нац. ун-ту залізн. трансп. ім. акад. В. Лазаряна. - 2011. - Вип. 38. - С. 233-237.

3. Вихідні данні Укрзалізниці стосовно показника собівартості 10 пас.-км та середньої дальності поїздки пасажира у приміському сполученні за 2010 рік.

4. Звіт 3 виконаної науково-дослідної розробки за договором № ПР/НРП - 11812/НЮ від 31.10.2011 p. Розробка порядку визначення ефективності курсування приміських поїздів за окремими напрямками Придніпровської залізниці.
5. Інструкції з калькулювання собівартості перевезень на залізничному транспорті України, затвердженої наказом Укрзалізниці від 15.01.2009 за № 015-Ц.

6. Момот А. В. Методичний підхід до визначення раціональних швидкостей руху пасажирських поїздів та раціональних зон їх курсування / А. В. Момот // Проблеми економіки транспорту: зб. наук. пр. Дніпропетр. нац. ун-ту заліз. трансп. ім. акад. В. Лазаряна. - Д. : Вид-во Дніпропетр. нац. ун-ту залізн. трансп. ім. акад. В. Лазаряна, 2013. - Вип. 5. - С. 80-89.

7. Номенклатура витрат з основних видів економічної діяльності залізничного транспорту України : Наказ Укрзалізниці від 21.08.2007 № 417-Ц. -414 c.

8. Пінчук О.П. Принципи побудови тарифів на перевезення пасажирів у приміському та регіональному сполучені / О.П. Пінчук // Вісник Дніпропетровського національного університету залізничного транспорту імені академіка В. Лазаряна.- Д.: Вид-во Дніпропетр. нац. ун-ту залізн. трансп. ім. акад. В. Лазаряна, 2011. - Вип. 38. - C. 270-276.

9. Пінчук О.П. Послідовність вирішення проблеми підвищення ефективності приміських пасажирських перевезень / О.П. Пінчук // Збірник наукових праць Дніпропетровського національного університету залізничного транспорту імені академіка В. Лазаряна «Проблеми економіки транспорту». - Д.: Вид-во Дніпропетр. нац. ун-ту залізн. трансп. ім. акад. В. Лазаряна, 2011. - Вип. 1. - C. 102.

10. Пінчук О.П. Концептуальний підхід до формування приміських пасажирських компаній та поїздів / О.П. Пінчук // Збірник наукових праць Дніпропетровського національного університету залізничного транспорту імені академіка В. Лазаряна «Проблеми економіки транспорту». - Д.: Вид-во Дніпропетр. нац. ун-ту залізн. трансп. ім. акад. В. Лазаряна, 2011. - Вип. 2 - С. 128.

11. Принципи визначення ефективності курсування приміських пасажирських поїздів на заданому напрямку руху / Ю. С. Бараш, Т. Ю. Чаркіна, Ю. П. Мельянцова, О. О. Карась // Вісн. Дніп-ропетр. нац. ун-ту залізн. трансп. ім. акад. В. Лазаряна. - Д. : Вид-во Дніпропетр. нац. ун-ту залізн. трансп. ім. акад. В. Лазаряна. - 2012. - Вип. 41. - C. 234-248.

12. Транспортна стратегія України на період до 2020 року, затверджена Кабінетом Міністрів України розпорядженням від 20 жовтня 2010 року № 2174.

13. Указ Президента України № 504/2011 «Про Національний план дій на 2011 рік щодо впровадження Програми економічних реформ на 2010-2014 роки «заможне суспільство, конкурентоспроможна економіка, ефективна держава». 
14. Чаркіна Т. Ю. Управління конкурентоспроможністю залізничних пасажирських перевезень на ринку транспортних послуг : автореф. дис. ... канд. екон. наук : 08.00.04 - економіка та управління підприємствами / Т. Ю. Чаркіна. - К. : Українська державна академія залізничного транспорту, 2013. - 22 с.

15. Звіт 3 виконаної науково-дослідної розробки за договором № 97/2012-ЦТех-248/2012ЦЮ від “ 18 ” жовтня 2012 Розробка програмного забезпечення із визначення ефективності курсування пасажирських поїздів.

16. Звіт 3 виконаної науково-дослідної розробки за договором № 62/11 - ЦТех - 117/2011 - ЦЮ від 22.08.2011 Розробка порядку визначення ефективності курсування пасажирських поїздів.

17. Кравченко X. В. Наукові принципи визначення ефективності курсування окремого пасажирського поїзда / Х. В. Кравченко, Ю. С. Бараш // Вісник ДНУЗТ ім..акад. В. Лазаряна. Д. 2011. - Вип. 40. - С.267-269

18. Методика розрахунку тарифів на перевезення пасажирів у внутрішньому сполученні. [Текст] / ДНУЗТ - Дніпропетровськ., 2010. - $76 \mathrm{c}$.

19. Бараш, Ю.С. Методичний підхід щодо визначення ефективності функціонування окремого приміського пасажирського поїзда [Текст] / Ю.С. Бараш, М.П. Сначов,
О.О. Матусевич, Х.В. Кравченко // Збірник наукових праць ДНУЗТ імені В. Лазаряна «Проблеми економіки транспорту». - 2014. - вип. 7. - c. $88-100$

20. Бараш, Ю.С. Методичний підхід щодо визначення раціональної зони курсування окремого денного швидкісного поїзда [Текст] / Ю.С. Бараш, О.О. Матусевич // Збірник наукових праць ДНУЗТ імені В. Лазаряна «Проблеми економіки транспорту». - 2015. - вип. 8. - с. 62-68

21. Калькуляція собівартості вантажних та пасажирських перевезень. Таблиця 1. К.: Укрзалізниця, 2011.

22. Бараш, Ю. С. Аналіз методики визначення витрат на пасажирські перевезення у дальньому сполученні / Ю. С. Бараш, М. П. Сначов // Вісник Дніпропетровського національного університету залізничного транспорту імені академіка В. Лазаряна. - Днепропетровск, 2008. Вип. 25. - С. 215-218

23. Indicators of Sustainable Development: Guidelines and Methodologies - Third edition. Methodology Sheets. - United Nations Development Pro-gramme. Environment and Energy Group Bureau for Development Policy. - 2008. - 398 p.

24. INFRAS/IWW 2004: External Costs of Transport: Update Study. Final Report. Zurich/Karlsruhe. - 2004.

\title{
РОЛЬ ЛОГИСТИКИ КАК МЕТОДОЛОГИИ РАЗВИТИЯ НАЦИОНАЛЬНОЙ ТРАНСПОРТНОЙ СИСТЕМЫ ТРАНЗИТНЫХ СТРАН
}

\author{
Елагин Ю.В., к.э.н., доцент (УкрГУЖТ)
}

В статье рассмотрен опыт использования логистики в качестве базовой методологии организации транспортной системы. Логистическая концепџия организации транспортной системы позволяет не только сокращать затраты, но и дает возможность получения значительных конкурентных преимуществ перед другими участниками рынка.

Логистическая интеграция разных видов транспорта позволяет повысить эффективность $u$ перейти от конкуренции между видами транспорта внутри страны к конкуренции с глобальными транспортными компаниями на международном транспортном рынке.

Ключевые слова: логистика, транспортная система, транзит.

\section{РОЛЬ ЛОГІСТИКИ ЯК МЕТОДОЛОГІЇ РОЗВИТКУ НАЦІОНАЛЬНОЇ ТРАНСПОРТНОЇ СИСТЕМИ ТРАНЗИТНИХ КРАЇН}

\author{
Слагін Ю.В., к.е.н., доцент (УкрДУЗТ)
}

У статті розглянуто досвід використання логістики в якості базової методології організаиії транспортної системи. Логістична концепџія організації транспортної системи дозволяє не тільки 